\title{
S1PR4 wt Allele
}

National Cancer Institute

\section{Source}

National Cancer Institute. S1PR4 wt Allele. NCI Thesaurus. Code C104780.

Human S1PR4 wild-type allele is located in the vicinity of 19p13.3 and is approximately 2 $\mathrm{kb}$ in length. This allele, which encodes sphingosine 1-phosphate receptor 4 protein, may play a role in cell migration processes in lymphocytes. 